\title{
A Contemporary Concept in Troubleshooting and Fixing Malfunctions Using an Engine Room Simulator in Augmented Reality Environment
}

\author{
Ivaylo Bakalov \\ Department "Ship Power Plants", Faculty of "Engineering", Nikola Vaptsarov Naval Academy, Vasil Drumev Str. 73, Varna, Bulgaria
}

Copyright $\mathrm{C} 2019$ by authors, all rights reserved. Authors agree that this article remains permanently open access under the terms of the Creative Commons Attribution License 4.0 International License

\begin{abstract}
Engine simulators are used to achieve the critical educational objectives in training the ship's crew. The simulators provide a complete scientific insight into systems, engines, machinery and everyday operation, as well as detection and fixing of problems. In addition, engine room simulators help teamwork, adaptation to different situations, and decision-making in a crisis situation. An exercise for seafarers was developed in a virtual LNG Carrier with Steam Turbine as main engine in the ERS TehSim 5000 simulation complex. The participants are divided into different teams: - for engine room team, and technical team. The exercise was developed on the basis of the ability of the marine engineers' training complex and the LNG Carrier vessel model on the simulator. The exercise consisted of work on the ship's steam system on LNG Carrier mixed with a real failure on the steam line. The engine room team operates on the simulated complex, and the technical team is dealing with the real work until troubleshooting. The exercise consists of: work on a real check list to start the power system; alarm sound; real work on the problem; implementation of emergency response procedures. The working staffs of the exercise are Greek students - fourth year mechanics, with experience of LNG Carrier.
\end{abstract}

Keywords Engine Simulators, Augmented Reality, LNG, Natural Gas, Teaching Methods

\section{Introduction}

The specific simulation model of an LNG Carrier Ship of the ERS TehSim 5000 simulator for marine engineers, which is integrated with the bridge simulator, provides feedback to the engine room. The operation and dealing with malfunctions of the ship power plant of such a ship operating on natural gas, is extremely important in response to the growing global demand for energy, which is accompanied by limited carbon dioxide emissions [1, 2, 3], demand for low carbon fuel, as well as demand for high-quality natural gas whose burning causes the least pollution of all hydrocarbons.

In case of malfunctions, trainees/operators respond in accordance with a check list or operation pattern. Quite often, technical malfunctions are present as a concomitant cause of accidents, but this cannot always be detected and reported. Augmented reality as an interaction approach provides unlimited opportunities to enhance the knowledge and skills of operators and trainees in real time and environment. The introduction of elements of augmented reality to a purely engineering environment such as working in the engine room (simulator) transforms the way engine room officers interact with technology and equipment, and provides unlimited access to knowledge [7, $8,9]$ - figure 1.

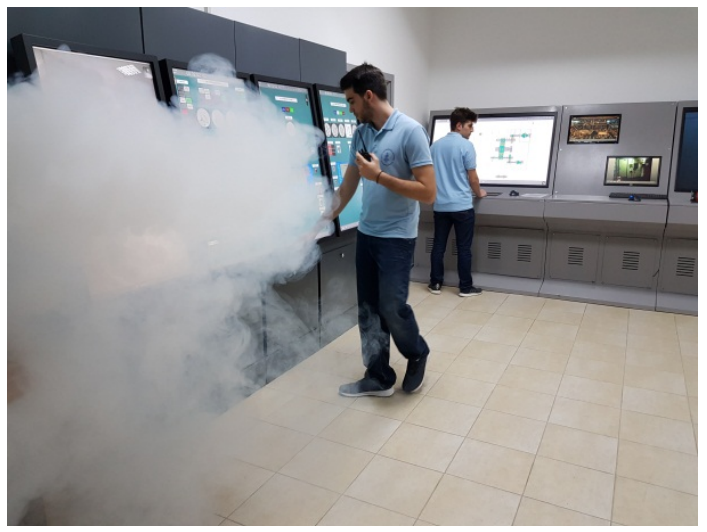

Figure 1. Case of malfunctions

\section{Problem Discussion}

The response to a situation/malfunction during a watch 
is always a challenge and a matter of training and experience. The skills and capabilities of each participant are sufficient for an initial stage of visualization and comparison of the problem with a previously known one. Whether the choice of the best approach to solving real situations is correct depends on both the personal qualities and the technical status of the equipment used. The simulator complexes provide an opportunity for practicing in a simulated environment, and the software stimulates the effective accumulation of knowledge and skills [10, 11, 12]. Costs and resources are also reduced compared to traditional ways of training ship engineers using real equipment. There are several factors directly affecting decision-making that cannot be taken into account when setting mathematical models with engine room simulators:

- Factor related to personality, and in particular that it is not a combination of different personal features but a dynamic organization that combines an individual and somewhat repetitive pattern of behavior;

- Factor related to theoretical orientation and methodical background. With sufficient practical and theoretical experience, everyone works following an approach and naturally conducts the work activity in a manner complying with requirements of the approach in question. This can create a problem because the followers of a specific approach are limited by its options for solving the problem. If there is any solution/approach, the options greatly increase, along with the difficulties involved in choosing the most appropriate and expedient way to solve a particular problem;

- A factor that depends directly on practical thinking. Ability to form a concept of solutions - right or wrong, which is the basis of critical- reflective thinking figure 2

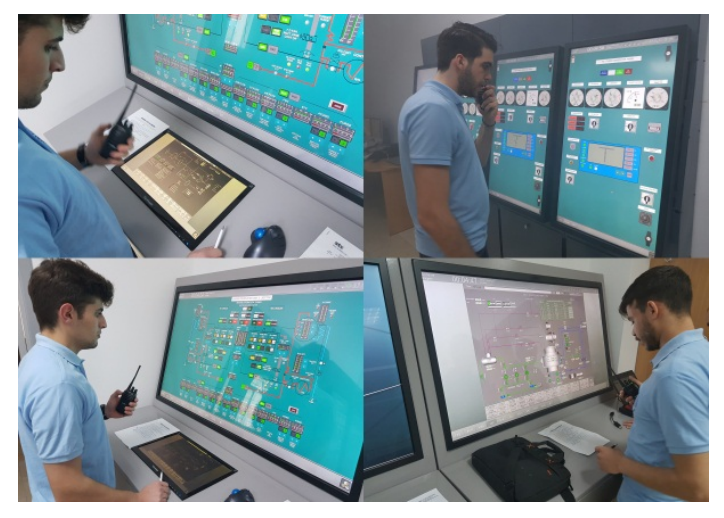

Figure 2. Decision-making

\section{Objective and Research Methodologies}

Carrying out the practical exercise which combines the work using a simulator and the actual work of material equipment at the same time, achieves a more realistic training of the ship staff. The experience gained during such an exercise is not only theoretical but is also directly focused on the self-confidence and self-discipline of each trainee. This type of exercise combines elements of visualization, real-time simulation, and human-computer interaction. The goals are to achieve an efficient and intuitive working environment, while developing and optimizing existing procedures and algorithms. The focus also lies with innovative solutions to ensure a convenient and efficient workflow of interactions [4].

Technological progress allows the use of innovative training tools. Research and scientific work related to similar engine simulator exercises and augmented reality are comparatively few in number and the technology itself is underdeveloped. The trend is to increase 3D models, but not the real equipment associated with the simulation complexes. The 3D environment can contribute to increasing the interest and motivation of engineers with more practical experience. However, the practical potential in the 3D environment is still being studied and further developed with the following goal - how to use the specific technology to promote personal improvement [5].

The article focuses on the use of the Augmented Reality for professional-personal improvement of ship engineers. Augmented reality (AR) [5] is part of Virtual Reality (VR), and while the trainee is" immersed" in the virtual world, around $\mathrm{him} / \mathrm{her}$, in the augmented reality, the real world with virtual objects is seen. Efforts can therefore be directed to mixing the virtual environment and making decisions within it, with the experience in a real environment, and suggesting a better approach to working with real equipment. Ideally, it would seem that the virtual and real objects and the actions that are being undertaken exist and are performed at the same time.

Some of the most important goals of such an innovative exercise are to promote the special and team interaction between the crew working in the engine control room /ECR/ - figure 3, and those working specifically to fix the malfunction. At a time when working together, part of the team can access shared space with virtual objects while remaining mainly in the real world. This approach is extremely useful for training and improvement as the trainees in a simulated environment can use communication (speech, gestures), but can also successfully plunge into the virtual environment mixed with augmented reality and can carry out "remote" collaboration. This is a positive feature of the augmented reality, allowing a person not to feel isolated in an environment, not having access to real equipment, but actually allowing a purely psychological factor - to "control" the environment and to have a real insight into the essence of a given a problem involving machinery or equipment.

The issue of safety is also of prime importance. Each crew member has to pass a specific set of safety-related 
courses. These are conducted in theoretical and practical lessons, but do not cover situations involving a combination of them. In an augmented reality environment where elements of the training practice are mixed with real practice ones, freedom of orientation, of action and interaction between the actual daily life and the emergency situation must be provided.
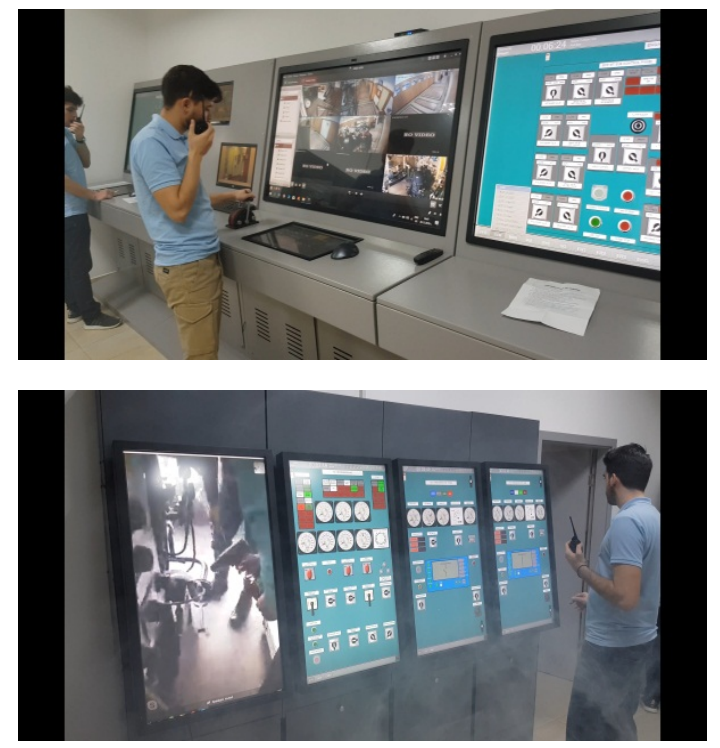

Figure 3. Engine control room /ECR/

Augmented reality cannot be an ideal solution for each and every approach and equipment, but this technology must always be related to the pedagogical goals and practice needs.

\section{Chronological Aspects of Creating Exercises in Augmented Reality Environment}

The development of each exercise in a new environment related to practical and operational direction should be addressed both from pedagogical and psychological aspects. There is no single approach to creating a scenario that meets all the needs and requirements to it. In the process of creation the scenario, it is important to know exactly which hierarchical level of the crew this exercise will be created for - support, operational, management level, or a combination of them. Development requires professional skills of people directly involved in the operation of a particular type of equipment. The participation of experienced people is important, as they can contribute with experience in creating the exercise scenario by refining each step. Pedagogical and didactic skills are also not to be underestimated because they are necessary to adapt the check list to the requirements of the users - the trainees. If special skills need to be treated and trained in a virtual space augmented with real equipment, a number of psychological aspects related to the personality should also be considered:
1) Individual differences reflected through the personality. Each individual is a unique combination and must be approached both personally and universally when creating the exercise;

2) Manifestation of personality consistency in time. A concept which allows estimates, statistics, and behavioral models in education;

3) Personal change. People evolve over time and with the experience gained, certain features are enhanced, others dwindle [6].

The environment must be restructured in such a way that the context of experience and knowledge is at the heart of the training. Interaction is a valid and reliable basis for the theory of teaching in a virtual environment. This interaction and teamwork is at the heart of building conceptual models of exchange of experience and information between those who are with better practical experience and those with more theoretical knowledge. This conceptual model is related to the chronological construction of an exercise directly linked to the crew's function, subject matter, interrelations, and the imposed constraints.

The proposed way of training in a virtual environment can be tailored to individual design requirements or peculiarities of the ship power plant due to the fact that the spatial orientation skill is an important component of human abilities.

Spatial capabilities cover five components [4]:

- Spatial perception. It is used to form professional experience (group/team);

- Spatial visualization. A deeper self-awareness and insight into a given problem is gained;

- Mental rotations. Capabilities needed in the orientation in the virtual environment where some of the elements may be presented in reverse order and space compared to the actual environment;

- Spatial relations. How to position an object relative to an object in a practical situation;

- Spatial orientation. The visual perceptions of the trainee can be analyzed and synthesized.

It is important to know that despite the positive aspects of the training based on innovative research, when the target knowledge is unstructured, the training process can be difficult. In order to adapt every approach to working with a check list to the needs of the specific training, a scheme how to conduct each exercise will also be proposed:

1) Teaching Approach: The instructor/teacher performs, explains and makes every step and emphasizes possible deviations from the normal state;

2) Real-life exercise: Each "step" is played and explained, guided by the instructor;

3) Analysis of the conducted exercise: It can also be in the form of a video lesson, and it is obligatory for the 
trainee to understand what is being done and encouraged to remember the chronology;

4) Assessment mode: An important point is self-assessment and offering the opportunity to achieve higher goals and the possibility of improvement.

\section{Conclusions}

In conclusion, it can be said that the practical value of this type of exercise and its educational effect are significant. At present, we are in the process of gathering experience and situations from practice to be embedded in the augmented simulated environment for real educational approaches. Despite the variety of options for working with different members and ranks of the engine department in real-virtual environments, creating scenarios requires substantial work and time. It is a substantial difficulty to connect and coordinate real equipment to the various ERS simulator models. Advances in the development of various pedagogical concepts, technologies, and approaches to operatinging modern ancillary systems and mechanisms require the need for an ever-increasing and necessary deepening of the virtual and augmented reality in initial and periodic training of ship engineers at operational and management levels. The pursuit is both to understand the effect of virtual and augmented reality, and to explore their unlimited potential.

Different approaches and teaching methods have been created with regard to the specific information and skills. The choice of innovations in training depends on the individual approach to the different technological innovations. Augmented reality is an approach/technology that quickly finds place in teaching, maintaining and developing habits and skills. Further research and solutions are needed in relation to the cost and effectiveness of the applied innovations, as well as feedback from the shipping companies, institutions and companies related to the maritime economy, shipbuilding, ship repair and shipping.

\section{Exercise Video}

https://www.youtube.com/watch?v=e93xV20JGjY the impact of air cooler contamination and wear of piston rings on the harmful emissions, 84-87.

[3] Hristov, D., Ivanov, I., Bakalov, I. (2018). Turbocharger Technical Condition Influence on the Carbon Dioxide Emmisions on Natural Gas Fueled Engine", First International Marine Engineering Conference, 187-191.

[4] Kaufmann, H. (2003). Collaborative Augmented Reality in Education, Institute of Software Technology and Interactive Systems Vienna University of Technology.

[5] Kangdon, L. (2012). Augmented Reality in Education and Training, Tech Trends.

[6] Kehayova-Stoycheva, M. (2008). Sotsialno-psihologicheski aspekti na potrebitelskoto povedenie, Ikonomicheski universitet - Varna.

[7] Nedev, A., Konsulova-Bakalova, M. (2009). Nov podhod za izgrazhdane na uchebnite planove po inzhenerni distsiplini" - sp. "Mashinostroene i Mashinoznanie", broy 5, godina IV, kniga 1.

[8] Nedev, A., Dimov, V., Kamberov, D., Kunev, G., Konsulova-Bakalova, M., Sezgin, S. (2009). Sistema za upravlenie na remontnata i obsluzhvashta deynost v korabite - sp. "Mashinostroene i Mashinoznanie", broy 6, godina IV, kniga 2, 21-23.

[9] Nedev, A., Dimov, V., Sezgin, S., Konsulova-Bakalova, M. (2010). Upravlenie na eksploatatsia v korabite sas smesen ogranichen rayon na plavane (KSORP), chrez formalna otsenka na riska, sp. "Mashinostroene i Mashinoznanie", broy 10 , godina $\mathrm{V}$, kniga 1, 34-38.

[10] Nedev, A., Konsulova-Bakalova, M., Nenov, H., Kamberov, D., Dimov, V., Sezgin, S., Antonov, G. (2010). Razpoznavane i prognozirane na sastoyanieto na energetichni uredbi i dvigateli, sp. "Mashinostroene i Mashinoznanie", broy 10, godina V, kniga 1, 39-43.

[11] Nedev, A., Bakalova, M., Dimov, V., Kamberov, D., Nenov, H., Antonov, G., Sezgin, S. (2010). Usavarshenstvan algoritam za razpoznavane i sistema za diagnostika na korabni dvigateli s vatreshno gorene, sp. "Mashinostroene i Mashinoznanie", broy 10, godina V, kniga 1, 44-48.

[12] Nedev A., Dimov, V., Kamberov, D., Kanev, D., Bakalova, M. (2008). Elementi za kompleksna avtomatizatsia na koraba, Spravochnik, Chast 4: "Avtomatizatsia na obshtokorabnite sistemi, palubnite mehanizmi i korabovodeneto (EKNIS, ECDIS)".

\section{REFERENCES}

[1] Hristov, D. (2017). Investigation of the effect of air cooler contamination and wear of the piston rings of marine engines on the specific fuel consumption, nitrogen and sulfur oxides, 363-366.

[2] Hristov, D., Ivanov, I., Hristov, H. (2018). Investigation of 